\title{
Correction to: Exploring the differences between men's and women's perceptions of gender-based violence in rural Tajikistan: a qualitative study
}

\author{
Elizabeth A. Wood ${ }^{1 *} \mathbb{D}$, Karina E. Wilson ${ }^{2}$ and K. D. Jacobs ${ }^{3}$
}

\section{Correction to: BMC Women's Health (2021) 21:91 https://doi.org/10.1186/s12905-021-01227-2}

Following publication of the original article [1], we were notified that the Reflexivity statement needs to be revised.

Originally published statement: "All three authors have been born and raised in the southern United States, are of upper-middle class, and white women."

Corrected statement: "All three authors have been born and raised in the Southern United States. K.W is an Asian-White biracial woman in lower-middle-class."

The original article has been corrected.
References

1. Wood EA et al. Exploring the differences between men's and women's perceptions of gender-based violence in rural Tajikistan: a qualitative study 2021;14:15. https://doi.org/10.1186/s12905-021-01227-2.

\section{Publisher's Note}

Springer Nature remains neutral with regard to jurisdictional claims in published maps and institutional affiliations.

\begin{abstract}
Author details
${ }^{1}$ Department of Environmental and Global Health, College of Public Health and Health Professions, University of Florida, 1225 Center Drive, P.O. Box 100182, Gainesville, FL, USA. ${ }^{2}$ College of Public Health and Health Professions, University of Florida, 1225 Center Drive, P.O. Box 100182, Gainesville, FL, USA. ${ }^{3}$ Social and Behavioral Science, College of Public Health and Health Professions, University of Florida, 1225 Center Drive, P.O. Box 100182, Gainesville, FL, USA.
\end{abstract}

Published online: 24 March 2021

The original article can be found online at https://doi.org/10.1186/s12905021-01227-2.

\footnotetext{
*Correspondence: liz07@phhp.ufl.edu

${ }^{1}$ Department of Environmental and Global Health, College of Public Health and Health Professions, University of Florida, 1225 Center Drive, P.O. Box 100182, Gainesville, FL, USA

Full list of author information is available at the end of the article
}

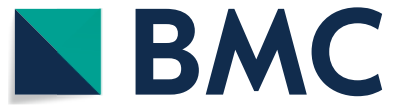

c) The Author(s) 2021. Open Access This article is licensed under a Creative Commons Attribution 4.0 International License, which permits use, sharing, adaptation, distribution and reproduction in any medium or format, as long as you give appropriate credit to the original author(s) and the source, provide a link to the Creative Commons licence, and indicate if changes were made. The images or other third party material in this article are included in the article's Creative Commons licence, unless indicated otherwise in a credit line to the material. If material is not included in the article's Creative Commons licence and your intended use is not permitted by statutory regulation or exceeds the permitted use, you will need to obtain permission directly from the copyright holder. To view a copy of this licence, visit http://creativecommons.org/licenses/by/4.0/. The Creative Commons Public Domain Dedication waiver (http://creativeco mmons.org/publicdomain/zero/1.0/) applies to the data made available in this article, unless otherwise stated in a credit line to the data. 